\title{
MEASURING INTERNAL AUDITOR'S INTENTION TO BLOW THE WHISTLE (A QUASI-EXPERIMENT OF INTERNAL AUDITORS IN THE LOCAL GOVERNMENT)
}

\author{
Abdul Hamid HABBE ${ }^{1}$, Syarifuddin RASYID ${ }^{2}$, Hermita ARIF $^{3}$, Iskandar MUDA ${ }^{4}$ \\ 1, 2, 3 Universitas Hasanuddin, Makassar, Indonesia \\ ${ }^{4}$ Universitas Sumatera Utara, Medan, Indonesia \\ E-mails: ${ }^{1}$ hamidhabbe@fe.unhas.ac.id; ${ }^{2}$ syarifuddinrasyid@fe.unhas.ac.id; \\ ${ }^{3}$ hermitaarif@fe.unhas.ac.id; ${ }^{4}$ iskandar1@usu.ac.id (corresponding author)
}

Received 09 December 2018; accepted 28 February 2019

\begin{abstract}
This study measures the cognitive moral development and tests its interaction with antecedent variables of prosocial behaviour such as fraud level, the status of person committing fraud and cohesiveness in affecting the willingness of internal auditors of local government (APIPs) to be a whistleblower. Quasi-experiment between subject design using pattern of $3 \times 2 \times 2 \times 2$ and $2 \times 2$ full factorial was employed in this research. The participants involved were internal auditors of 24 local governments in South Sulawesi which were divided into 18 groups. The data were analysed using ANOVA and t-test. The results of this study showed that based on the Cognitive Moral Development (CMD), majority of the internal auditors were categorised as pragmatic, the least number were autonomous, while accommodation was in between of both. Moreover, the intention of APIP to whistleblow was found high though insignificantly different among the three categories of CMD. Similarly, the different was insignificant among the variance of fraud level, the status of person committing fraud, and cohesiveness. The interaction between CMD and treatment variables resulted insignificant figure, except for the interaction between CMD and the fraud level which indicated significant result. Generally, it can be concluded that APIPs have a high intention to blow, but the intention will differ when their CMD interact with the fraud level and cohesiveness.
\end{abstract}

Keywords: cognitive moral, Fraud, position, status, prosocial behaviour, cohesiveness, whistleblower.

JEL Classification: H70, M41, M42.

\section{Introduction}

Whistleblowing is one of the effective way to decrease the corruption level. This is because it is conducted by parties within an organisation possessing access and understanding the operational aspect of organisation. This would be expected to be more effective if it is executed by internal auditor of a company. However, the problem raised when not all of the internal member of a company is willing to be a whistleblower for their workplace. Various factors could be the consideration as explained by prosocial behaviour theory. Whistleblowing has been defined as an act of a person who believes that the interest of public is beyond the interest of organisation leading him to disclose any corruption, illegal or illegitimate practices within his workplace
(Nader 1972 in Vandekerchove 2006). Whistleblowing is considered as a prosocial behaviour.

This study is to test factors influencing one's willingness to whistleblow. Research would be designed as an experiment involving internal auditors of local government as participant (inspectorates). The considerations are, firstly, inspectorates are internal parties of local government who understand the governmental sector operation. This is consistent with Jubb $(1999,2000)$ and Tsaharidu and Wim (2008) proposing that internal auditors knows about the details of organisation better than others since they have access to essential information. Secondly, inspectorates are in the position of supervising and controlling the governmental operation thus would be knowing if there is an indication of fraud. Thirdly, they are considered as partner

Copyright (C) 2019 The Authors. Published by VGTU Press.

This is an Open Access article distributed under the terms of the Creative Commons Attribution License (http://creativecommons.org/licenses/by/4.0/), which permits unrestricted use, distribution, and reproduction in any medium, provided the original author and source are credited.. 
for the Audit Board of the Republic of Indonesia (BPK RI), auditing the respective institution. Being responsible for those roles, inspectorates are consequently at the best position to be whistleblower for the BPK. This is supported by Arnold and Ponemon (1991), Miceli (1994), and Xu and Ziegenfuss (2008) suggesting that internal auditors of a company are highly potential to whistleblow.

Prosocial behaviour theory could be used to explain the willingness of someone to be a whistleblower. This theory recommends prosocial behaviour as an act conducted by member of an organisation against another member, group, or organisation which is intended to increase the welfare of individual, group, or the respective organisation. This objective could be disrupted with the presence of fraud or corruption which in turn will obstruct the economic growth (Brief and Motowidlo 1986). Prosocial behaviour theory offers two antecedent variables which may influence someone to behave prosocially. The first variable is individual antecedent such as feeling of empathy, social responsibility, level of education, and motivation. This type of antecedent is inherent to a person (Hill 1982). The second variable is contextual antecedent such as prevailing norms, group cohesiveness, scope of work, role clarity, leadership style, and participation in decision making. Both groups of these variables may influence each other (Rushton et al. 1981, Brief and Motowidlo 1986). Additionally, the form and level of fraud as well as the status of person engaging fraud are also considered as contextual antecedent factors that influence the internal auditor's decision to act as a whistleblower.

Several studies of antecedent factors influencing the whistleblowers' intention have been previously done. Schultz et al. (1993), Kaplan and Whitecotton (2001), Ayers and Kaplan (2005) examined the relationship between fraud seriousness, personal cost, and responsibility and the willingness of someone to be a whistleblower. Ahmad (2011), on the other hand, evaluated the influence of organisational, individual, situational, and demographic factors on internal auditors' intention to whistleblow. Sabang (2013) studied the fraud, the status of wrongdoer, and individu-group interaction in their relation to the governmental internal auditors' intention to whistleblow. Furthermore, King (1997), Greenberger et al. (1987), Miller and Thomas (2005) examined the closeness of relationship (cohesiveness) between the wrongdoer and whistleblower interacting with the seriousness of fraud. The individual-group interaction factors that exist within the auditor group was also taken into consideration by most of the previous researches.

Internal factor of antecedent which is also considerable highly influential that is absent in Prosocial behavior theory is cognitive moral development. The cognitive moral level determines one's perspective and his direction in the universality of truth. People who have reached autonomous level will tend to prioritize the interest of society over others (Kohlberg 1971, 1977). Therefore, this group would be highly potential to be whistleblower as compared to accommodation and pragmatic group. The involvement of cognitive moral development in whistleblowing researches is crucial as it will be able to answer the lack of willingness of internal auditors to whistleblow within their organisation. In addition to other antecedent factors, the low cognitive moral of internal auditors possibly contributes to the ineffectiveness of whistleblowing system in Indonesia. Habbe et al. (2017) in their experimental study which involved Postgraduate students of University of Gadjah Mada and University of Hasanuddin respectively, found that their average cognitive moral was mostly at pragmatic level, while those with autonomous levels were only less than $10 \%$ of the total number of participants.

The effectiveness of whistleblowing system in Indonesia is crucial for good corporate governance as a means to control opportunistic behaviour. The remainder of this paper is organised as follows. Sections two deliberates the literatures review and previous studies on cognitive moral theory, prosocial organizational behavior theory (Hofstede 1980) and the antecedent variables that influence whistleblowing behaviour. Section three describes research methodology used which consist of quasi experiment method and procedure with all the relevant parameters as well as its analysis model. Section four presents the empirical data and its analysis followed by section five which elaborates results and discussions. Finally, section six summarizes the findings and proposes recommendation for future research.

\section{Literature review}

Two underlying theories used in this study are Kohlberg's cognitive moral development $(1971,1977)$ and prosocial organisation behaviour theory (Brief and Motowidlo 1986). These both theories could be used to explain the interaction between one's cognitive moral stage and antecedent variables such as fraud level, the status of wrongdoer and cohesiveness, in measuring the interest of internal auditors in the local government to act as a whistleblower within their workplace of institution.

\subsection{Cognitive moral development}

Kohlberg $(1971,1977)$ proposed that cognitive development is personal value gained through a process of thought and expression. Kohlberg designed moral development stages started from a simple consequence which was the effect of personal discomfort from outside on behaviour, to appreciation and awareness of the universality of humanities (Elias et al. 1989). Assumptions underlying Kohlberg's theory are as follows. Firstly, in order to understand one's moral behaviour, it is important to understand his moral philosophy 
which is fundamental reason driving his action. Secondly, the level of cognitive moral development is structured as a comprehensive way of thinking. Every person will consistently follow his moral consideration stage. Thirdly, the concept of cognitive moral development describes a series of developmental sequence which is universal in nature and applicable in any culture setting. The higher the cognitive moral of someone, the higher he respects others' right. The cognitive moral development, as explained by Kohlberg (1977), consists of three stages; pragmatic, accommodation, and autonomous.

\subsection{Prosocial Organizational Behavior Theory}

In general, prosocial behaviour is an action performed by an organisation member toward another individual, group, or organisation which is intended to improve the welfare of the respective individual, group, or organisation. This is consistent with definition proposed by Brief and Motowidlo (1986) stating that:

"Prosocial organizational behavior is behavior which is (a) performed by a member of an organization, (b) directed toward an individual, group, or organization with whom he or she interacts while carrying out his or her organizational role, and (c) performed with the intention of promoting the welfare of the individual, group, or organization toward which it is directed"

The motive of a person to act as a whistleblower is not always due to altruistic. Selfish motivation or personal goals can also trigger a person to whistleblow. Dozier and Miceli (1985) suggested that whistleblowing is a form of prosocial behaviour driven by either selfishness or altruistic.

Brennan and Kelly (2007) identifying a five-step approach that someone will go through to be a whistleblower; firstly, the observer must be aware of the existence of wrongdoing; secondly, he must decide whether it warrants action; thirdly, he must decide whether he is responsible to take such action; fourthly, an appropriate method of action must be selected; and finally, to execute the action. This procedure raises an ethical dilemma in the ethical decision making process for someone to blow the whistle (Brennan and Kelly 2007). On the other hand, Greenberger et al. (1987) suggested six steps of decision process that precede whistleblowing. Step 1, the focal member considers whether the activity is wrong. Step 2, to decide whether the situation deserves of action and then to decide whether he is responsible to take such action (step 3). Next step, he considers whether efficacious actions are available (step 4) and again considers whether these actions are appropriate (step 5). Finally, in the step 6, he considers whether the expected benefits of action outweigh the expected costs.

Prosocial organisational behaviour theory consists of several antecedent variables. Brief and Motowidlo (1986) summarised diverse literatures on prosocial behaviour that determinant variables of prosocial behaviour can be organized into two general themes, individual antecedent, and contextual antecedent.

\subsection{Whistleblower and auditor}

The definition of whistleblowing in general is as explained by Brennan and Kelly (2007).

"... the disclosure by organization members (former or current) of illegal, immoral, or

illegitimate practices under the control of their employers, to persons or organizations that may be able to effect action."

Vandekerchove (2006), on the other side, defined whistleblower as a person who believes that public interest is more important than the interest of organisation employing him, thus, willing to disclose corruptions, illegal acts, cheatings, or other detrimental doings within organisation.

According to the Witness and Victim Protection Agency of Indonesia (2011), the criteria of whistleblower are as follow. Firstly, report or disclose the fraud or illegal act to an authorised agency or to mass media or public in order for the said agency to reveal such fraud. Secondly, whistleblower is an insider, a person who reveals alleged offenses or crimes that occurred in the company he is working in. Based on those criteria, the internal auditors of government have chance to be whistleblower (Sabang 2013).

The Government Regulation No. 8 of 2006 on Financial and Performance Reporting of Government Agencies, chapter 33 verse 3 states that the internal supervisory body working in each state ministries, agencies, or local government should conduct a review upon financial statement presented before being submitted to the Audit Board of the Republic Indonesia. Supportedly, according to Act No. 15 of 2004 on Audit of State Financial Management and Accountability chapter 9 verse (2), the result of auditing conducted by inspectorates should be submitted to the Audit Board of the Republic Indonesia.

\subsection{Hypotheses development}

\subsubsection{Cognitive moral development and whistleblower}

Cognitive moral development stage is one of the determining factor in an ethical decision making behaviour. The higher the cognitive moral of someone, the higher he respects others' right. The cognitive moral development, as explained by Kohlberg (1971), consists of three stages, pragmatic, accommodation, and autonomous. The first stage refers to an individual as personal, second stage considers interpersonal relationship, and the third is one's belief in the principle of moral universality. It is predicted that the probability of one's willingness to whistleblow would differ according to his cognitive moral stage. An auditor 
that has reached autonomous stage is assumed to act based on altruistic values. The perception of righteousness and fraud has been universal in nature (Miceli and Janet 1985). Therefore, the first hypothesis of this research are as follow. According to Kohlberg's cognitive moral development assumption, the higher the moral development of someone, the higher they will value others' right. Thus, internal auditor with high cognitive moral stage will highly tend to act as a whistleblower. Autonomous is the group with the highest cognitive moral development, pragmatic is classified as the lowest, while pragmatic is in between of both group. Based on this theory, the second hypothesis is formulated as follows.

H1: The willingness of internal auditors to become whistleblower differs among the three groups of cognitive moral of pragmatic, accommodation, and autonomous.

H2: The willingness of internal auditors to become whistleblower is highest for autonomous group, lowest for pragmatic group, and accommodation group is in between the two.

\subsubsection{Prosocial Organizational Behavior Theory and whistleblower}

Prosocial organizational behavior is an action undertaken voluntarily by a member of an organization that is directed toward an individual, group, or organization to promote the welfare of the individual, group, or organisation (Hofstede 1997). It carries out two antecedent variables, individual and contextual variable (Brief and Motowidlo 1986).

\section{Fraud Level}

Fraud level is an important factor to consider to be reported by internal auditors. The higher the losses or damage caused by the fraud committed, the higher the opportunity for those who are aware of it or get impacted to report that wrongdoing. This is confirmed by Schultz et al. (1993), Kaplan and Whitecotton (2001), Ayers and Kaplan (2005) in their study which tested the relation between fraud seriousness, personal cost, and responsibility with one's willingness to whistleblow. Fraud level is often measured based on its moral issue consequences (Jones 1991). Prosocial is indirectly stating that the risk of both material and moral as the consequence of high fraud level will trigger someone to whistleblow. Based on this, the third hypothesis is formulated as follows.

H3: The willingness of internal auditors to become whistleblower will be greater if the degree of fraud is high than if the degree of fraud is low

\section{The Status (Position) of the Wrongdoer}

The higher the position of someone, the higher his selfesteem and increasing dislike to be humiliated. Miceli et al. (1999) who observed state officers after the issuance of Protection Act for the whistleblower concluded that the fraud reporting increased. However, they used anonymous due to revenge consideration they have experienced. These findings indicate that whistleblowing the illegal act conducted by person with high position will incur relatively high risk. Revenge or ostracism action by the official committing fraud is not merely due to the career concern of the respective wrongdoer, but also for the interest of organisation. The high position of the wrongdoer within organisation will further strengthen him to taka revenge if anyone is trying to perform an investigation. Goodwin and David (1999) stated that high power distance will potentially cause one's ignorance against his boss' unethical behaviour. Conversely, low power distance will tend to encourage an individual to oppose unethical behaviour.

H4: Internal auditors' intention to whistleblow is greater for low-level wrongdoer than for high level

\section{Auditor-Wrongdoer Cohesiveness}

Eastern people are found to have higher collectivity compared to western people (Hofstede 1980). Indonesian society as part of eastern community is possessing high level of collectivity which describes level of closeness. Tavakoli et al. (2003) employed Hofstede's typology to observe the willingness of employee of the same company in Kroasia and the US to become whistleblower. Patel (2003) examined that whistleblowing as part of controlling system would be more effective in an individualistic country. Miller and Thomas (2005) suggested that the intention to whistleblow the fraud is influenced by relational closeness (relationship in the context of cohesiveness). Tharp and Mattingly (1991) in Miller and Thomas (2005) identified that the decreased willingness to disclose illegal act in hospitals was due to the presence of loyalty among the nurses.

Cohesiveness is one of antecedent variables of prosocial behaviour (Brief and Motowidlo 1986). The nature of relationship between two individuals influences the likelihood of a person to behave prosocially against the other (Clark 1981, Clark and Mills 1979). King (1997) found that the likelihood of reporting a wrongdoing is influenced by the relational closeness between the observer and the wrongdoer. Hence, people would be less likely to report their close colleague who has committed fraud to an immediate supervisor. Likewise, Greenberger et al. (1987) indicated that group members of a company would try to persuade the whistleblower to remain silent in response to an unethical behaviour within organisation. Based on those illustrations, the following hypothesis is formulated.

H5: The willingness of internal auditors to become whistleblower is greater if the cohesiveness between wrongdoer and internal auditor is low than if the cohesiveness is high

\section{Interaction between variables}

Brief and Motowidlo (1986) stated that individual and contextual antecedent variables covary each other in influencing one's interest to blow the whistle. Based on this 
explanation, the following is the last hypothesis of this research.

H6: The interaction between antecedent variables in influencing internal auditors' willingness to become whistleblower differs according to cognitive moral stage.

\section{Methodology}

This study employs quasi experiment in addressing the proposed hypotheses. This method is considered relevant as this study involved large number of internal auditors in local government as participants and they work on the experiment treatment in their workplaces, a situation where laboratory experiment is not possible. The experiment model was designed with a full factorial format and tested using ANOVA. In this study using a quasi-experimental design (quasi experiment). The quasi-experimental design is a research design experiment conducted in conditions that do not allow controlling or manipulating all relevant variables. The researcher is not able to control all variables that are able to influence. Therefore the design of this experiment is often considered an inaccurate experiment.

\subsection{Research subject}

The subjects of this study are internal auditors (inspectorates) working in local government of 24 regencies/cities in South Sulawesi. South Sulawesi was selected since it was one of the inspected institutions by the Audit Board of

Table 1. $2 \times 2$ Experiment Design - Fraud Level $\times$ Wrongdoer's Status (source: Research design 2018)

\begin{tabular}{|l|l|c|c|}
\hline \multicolumn{2}{|c|}{ Variable and Level } & \multicolumn{2}{c|}{ Fraud Level } \\
\cline { 3 - 4 } & Low & High \\
\hline \multirow{2}{*}{$\begin{array}{l}\text { Wrongdoer's } \\
\text { status }\end{array}$} & Low & & \\
\cline { 2 - 4 } & High & & \\
\hline
\end{tabular}

Table 2. $2 \times 2$ Experiment Design - Fraud Level $\times$ AuditorWrongdoer Cohesiveness (source: Research design 2018)

\begin{tabular}{|l|l|c|c|}
\hline \multicolumn{2}{|c|}{ Variable and Level } & \multicolumn{2}{c|}{ Fraud Level } \\
\cline { 3 - 4 } & Low & High \\
\hline \multirow{2}{*}{ Cohesiveness } & Low & & \\
\cline { 2 - 4 } & High & & \\
\hline
\end{tabular}

Table 3. $2 \times 2$ Experiment Design: Wrongdoer's Status $\times$ Auditor-Wrongdoer Cohesiveness (source: Research design) 2018)

\begin{tabular}{|c|c|c|c|}
\hline \multirow{2}{*}{\multicolumn{2}{|c|}{ Variable and Level }} & \multicolumn{2}{|c|}{ Wrongdoer's Status } \\
\hline & & Low & $\mathrm{High}$ \\
\hline \multirow{2}{*}{$\begin{array}{l}\text { Auditor- } \\
\text { Wrongdoer } \\
\text { Cohesiveness }\end{array}$} & Low & & \\
\hline & High & & \\
\hline
\end{tabular}

the Republic Indonesia in the first semester of 2016. The respondents are all the internal auditors both structural and functional at all level of position. The reason for this criteria determination is because auditing which is performed by an inspectorate involves both structural and functional officials.

\subsection{Case design}

There were nine cases to observe in this study. Three cases to measure cognitive moral development, two cases to identify high and low level of wrongdoing, the next two cases are the status of wrongdoer, high or low position, and the last two are the case where the wrongdoer has close relationship with internal auditor. Cases to measure CMD were adopted from IDT while fraud cases occupied the real audit findings in local governments by the Audit Board of the Republic Indonesia. This research is adopting Sabang's model (2013) with various treatment manipulations.

\subsection{Design of experiment}

This study employed quasi-experiment between subject designs of $3 \times 2 \times 2 \times 2$ full factorial (Habbe and Mande 2016). Cognitive moral development consisted of three levels; pragmatic, accommodation, and autonomous; fraud was divided into two level of low and high; the status (position) of the wrongdoer was classified as low and high; cohesiveness strength of low and high. Experiment between subject design models was used to examine the difference of internal auditors' intention to whistleblow in every level of category of cognitive moral, fraud, status of wrongdoer, cohesiveness, and interaction between these variables. Participants were divided into 18 groups according to the number of cell in experiment model of $3 \times 2 \times 2 \times 2$. Each group was treated differently. The group was based on region inspectorates in South Sulawesi. The other factorials were tested using model $2 \times 2$ as shown in Table 1 . The distribution of the experiment scenario and research questionnaire to the respondents across 24 regencies/cities in South Sulawesi has been done.

The other factorials were tested using model $2 \times 2$ about The Experiment Design-Fraud Level $x$ Auditor-Wrongdoer Cohesiveness as shown in Table 2 as a follows:

The Table 3 shows that the $2 \times 2$ Experiment Design: Wrongdoer's Status x Auditor-Wrongdoer Cohesiveness as a follows:

\subsection{Variables and measurement}

Dependent variable examined in this study is whistleblowing willingness. Decision to become whistleblower is expressed in one statement. Respondents were asked to answer all question in each scenario using seven-point scale, from 1 for least possible to 7 for most possible. The 
case of fraud dilemma was manipulated into 6 scenario which were tested in 3 level of cognitive moral, thus the total of scenario is 18 .

Independent variables in this research are cognitive moral development (CMD) consisting of 3 stages (pragmatic, accommodation, and autonomous), fraud level (low, high), position (low, high), and cohesiveness (low, high). Cognitive moral development is the stage of cognitive moral, as explained by Kohlberg (1984) composites of 3 level which are pre-conventional, conventional, and postconventional. The first level focuses on oneself as personal, the second level refers to personal relationship, and the third level concerns on one's belief in the universal principles. This Kohlberg's CMD would be examined using DIT. Only 3 out of 6 scenario were hired. The reason for the drop of the three cases is to reduce the mortality threat which was quite high in the previous study. Rest $(1979,1994)$ suggested that the reliability level of Cronbach Alfa coefficient of 3 cases DIT could reach point of 0.70 s. The answer of respondents for each story based question will measure their CMD level. The categorisation of CMD score would be made as less than 27 , between $27-41$, and more than 41 which would be then classified as pragmatic, accommodation, and autonomous respectively.

\subsection{Experiment procedures}

Procedures of this experiment are as follow.

a. Participants were divided according to their inspectorate institution. Hence, there was no similar scenario for each institutions

b. Participants began the experiment by reading the experiment instruction and then fill up the identity form such as name, institution, age, gender, educational background, auditing experiences, job position, and number of audit trainings they have attended

c. Participants were asked to read through the scenario one to three, answer all the questionnaire for each scenario based on their readings, and rank their answer

d. Next step was to perform the experiment. Participants were asked to read the given cases carefully upon which they would answer some questions to test their understanding on the scenario (manipulation check).

e. Based on the fraud dilemma scenario given, they would finally determine their decision to or not to whistleblow.

\subsection{Data analysis}

Data were analysed using Four-way ANOVA, Two-way ANOVA and T-test. ANOVA test is used to test four-way and two-way interaction hypotheses for all interactions while T-test is used to test the mean difference of internal auditors' willingness to blow the whistle based on treatment variables.

\section{Empirical data and analysis}

\subsection{Descriptive statistics}

This study is to examine the factors influencing an inspectorate's willingness to be a whistleblower. Factors to test in this research were cognitive moral development and antecedent variables of prosocial behaviour such as fraud level, the position status of wrongdoer, and cohesiveness between the wrongdoer and the whistleblower. Internal auditors (inspectorates) of local governments in 24 regencies/ cities of South Sulawesi were observed. There have been 565 (58.85\%) questionnaires returned from 20 regencies, of which only 553 completely answer the survey questions and fulfil criteria to be processed and analysed. The following Table 4 presents the descriptive statistics of participants.

Table 4 illustrates the characteristics of participants of this study. The average age, working experiences in auditing, and the number of audit training they have been attending are 40.73 years, 7.45 years, and 6.2 times respectively.

Based on Table 5 from 553 respondents, there are 117 sit on structural position and the remainings serve as functional auditor comprising of 137 senior auditor, 183 junior auditors, and 69 middle auditors. The number of female are 223 and the remaining 215 are male participants.

\subsection{Experiment situation}

Table 6 shows the categories of respondents' cognitive moral development (CMD). Of the 553 participants, only 89 persons are categorised as autonomous (highest CMD), majorly are being pragmatic (lowest CMD) which are 292 persons, while the rest 172 are accommodation group.

Table 4. Descriptive Statistics of Participants (source: SPSS Output Result 2018)

\begin{tabular}{|l|c|c|c|c|}
\hline \multicolumn{1}{|c|}{ Indicator } & Minimum & Mean & Maximum & $\begin{array}{c}\text { Deviation } \\
\text { Standard }\end{array}$ \\
\hline Age (year) & 21 & 40.73 & 59 & 8.30 \\
\hline $\begin{array}{l}\text { Experiences } \\
\text { (year) }\end{array}$ & 1 & 7.45 & 10 & 2.65 \\
\hline $\begin{array}{l}\text { Trainings } \\
\text { (frequency) }\end{array}$ & 1 & 6.2 & 10 & 2.81 \\
\hline
\end{tabular}

Table 5. Descriptive Statistics of Participants (source: SPSS Output Result 2018)

\begin{tabular}{|l|c|c|c|c|c|}
\hline $\begin{array}{c}\text { Position } \\
\text { and } \\
\text { Gender }\end{array}$ & $\begin{array}{c}\text { Struc- } \\
\text { tural }\end{array}$ & $\begin{array}{c}\text { Senior } \\
\text { Auditor }\end{array}$ & $\begin{array}{c}\text { Junior } \\
\text { Auditor }\end{array}$ & $\begin{array}{c}\text { Middle } \\
\text { Auditor }\end{array}$ & Total \\
\hline Position & 164 & 137 & 183 & 69 & 553 \\
\hline $\begin{array}{l}\text { Gender } \\
\text { M (F) }\end{array}$ & $90(74)$ & $84(53)$ & $107(76)$ & $49(20)$ & $330(223)$ \\
\hline
\end{tabular}


Table 6. Experiment Situation and Whistleblowers' Score $3 \times 2 \times 2 \times 2$ (source: SPSS Output Result 2018)

\begin{tabular}{|c|c|c|c|c|c|}
\hline \multirow{2}{*}{\multicolumn{2}{|c|}{ Variable and Level }} & \multicolumn{3}{|c|}{ Cognitive Moral Development } & \multirow{3}{*}{$\begin{array}{c}\text { Total } \\
5.61(66)\end{array}$} \\
\hline & & \multirow{2}{*}{$\frac{\text { Pragmatic }}{4.71(38)}$} & \multirow{2}{*}{$\frac{\text { Accomodation }}{6.01(18)}$} & \multirow{2}{*}{$\begin{array}{c}\text { Autonomous } \\
6.10(10)\end{array}$} & \\
\hline & Low & & & & \\
\hline rraud Lever (rL) & High & $5.69(254)$ & $5.62(154)$ & $5.72(79)$ & $5.68(487)$ \\
\hline \multirow{2}{*}{ Position Level } & Low & $5.57(168)$ & $5.39(95)$ & $5.77(30)$ & $5.58(293)$ \\
\hline & High & $5.56(124)$ & $5.99(77)$ & $5.76(59)$ & $5.77(260)$ \\
\hline \multirow{2}{*}{$\begin{array}{l}\text { Cohesiveness Auditor- } \\
\text { Wrongdoer (CAW) }\end{array}$} & Low & $5.51(277)$ & $5.74(152)$ & $5.89(76)$ & $5.71(505)$ \\
\hline & High & $5.57(15)$ & $5.00(20)$ & $5.00(13)$ & $5.56(48)$ \\
\hline Total & & $5.57(192)$ & $5.66(172)$ & $5.76(89)$ & $5.62(553)$ \\
\hline
\end{tabular}

Table 6 demonstrates the whistleblower's score for the main model of $3 \times 2 \times 2 \times 2$ : CMDxFLxWSxCAW. There are 18 cells in that interaction combinations. The figure of each cell shows the willingness of the respondents to whistleblow within their institution. The range of score is started from 1 (least possible) to 7 (most possible). The figures presented in the brackets are the number of respondents in each cell. The figure in each cell exhibits average score between 5 and 6. It is also presented in the table that the highest score of willingness to be whistleblower is possessed by autonomous group which is 5.76 out of 7 , followed by accommodation with the score of 5.66, while the pragmatic group indicates the lowest score of 5.57. Moreover, the average total score for each treatment level of both fraud level and wrongdoer's status case presents higher score for high-level treatment than the low-level treatment.

\subsection{Statistical analysis}

The willingness differences of internal auditors to become whistleblower as a follows in Table 7.

Table 7 exemplifies that the highest score of whistleblower (5.76) is shown by autonomous group, followed by accommodation group having score of 5.66, and pragmatic group with 5.57 score. This difference is statistically insignificant indicated by F-value of 0.509 and p-value of 0.601 . This statistical results show that there is no significant willingness difference of internal auditors among the three $\mathrm{CMD}$ groups to become whistleblower. The expectation that

Table 7. Score differences of Whistleblower Based on CMD (source: SPSS Output Result 2018)

\begin{tabular}{|l|c|c|c|c|}
\hline \multirow{2}{*}{} & \multicolumn{4}{|c|}{ Cognitive Moral Development } \\
\cline { 2 - 5 } & Pragmatic & $\begin{array}{c}\text { Accomo- } \\
\text { dation }\end{array}$ & $\begin{array}{c}\text { Auto- } \\
\text { nomous }\end{array}$ & Total \\
\hline $\begin{array}{l}\text { Score of } \\
\begin{array}{l}\text { Whistle- } \\
\text { blower }\end{array}\end{array}$ & $\begin{array}{c}5.57 \\
(\mathrm{n}=292)\end{array}$ & $\begin{array}{c}5.66 \\
(\mathrm{n}=172)\end{array}$ & $\begin{array}{c}5.76 \\
(\mathrm{n}=89)\end{array}$ & $\begin{array}{c}5.63 \\
(\mathrm{n}=553)\end{array}$ \\
\hline $\begin{array}{l}\text { Statistical } \\
\text { figure }\end{array}$ & $\mathrm{F}=0.509$ with P Value $=0.601$ \\
\hline
\end{tabular}

the intention of autonomous group to whistleblow would be higher than the other two groups, as hypothesized, is not empirically proven. Therefore, $\mathrm{H} 1$ and $\mathrm{H} 2$ are both rejected. The effect of different CMD level on the APIPs' interest to whistleblow is undermined by attitudes and commitments to proritise the interest of organisation and society. This fact supports the prosocial behavioral theory that public and organizational interests take precedence over individual or group interests (Hofstede et al. 2010). The phenomenon of many upper-level governmental officals alleged to have committed abuses is of the contribution of whistleblowing action from internal auditors. Arnold and Ponemon (1991), Miceli et al. (1991) and Xu and Ziegenfuss (2008) affirmed this statement that internal auditors within a company are potentially acting as whistleblowers.

The willingness differences of internal auditors to whistleblow in all treatments

Table 8 presents the statistical difference result of willingness score of internal auditors to act as whistleblower in three conditions; fraud level, wrongdoers' status, and cohesiveness. Despite the fact that the score of willingness differs between low and high level in all treatments, it is statistically insignificant. T-value in each difference does not imply significant $p$-value. This result indicates that, in general, internal auditors will take decision to blow the whistle in all conditions. They are not impacted by fraud

Table 8. Score differences of whistleblowers' willingness in three treatments (source: SPSS Output Result 2018)

\begin{tabular}{|l|l|l|l|}
\hline \multicolumn{1}{|c|}{ Level } & \multicolumn{1}{|c|}{ Fraud Level } & Position Level & \multicolumn{1}{c|}{ Cohesiveness } \\
\hline Low & $5.27(66)$ & $5.53(293)$ & $5.64(505)$ \\
\hline High & $5.67(487)$ & $5.73(260)$ & $5.52(481)$ \\
\hline Statistics & $\begin{array}{l}\mathrm{T}=-1.802 ; \\
\mathrm{p}=0.074\end{array}$ & $\begin{array}{l}\mathrm{T}=-1.412 ; \\
\mathrm{P}=0.156\end{array}$ & $\begin{array}{l}\mathrm{T}=0.447 ; \\
\mathrm{p}=0.655\end{array}$ \\
\hline
\end{tabular}


level, position of the wrongdoer, and cohesiveness relationship. Hence, it can be inferred that $\mathrm{H} 3, \mathrm{H} 4$, and $\mathrm{H} 5$ are not empirically proven.

\section{Interaction between CMD and treatment variables}

Table 9 demonstrates the interaction between CMD and the three treatment variables. In the case of wrongdoer's position level (status) and CMD, individually and in interaction, it statistically shows that there is no significant difference of willingness of internal auditors to whistleblow. But, this is different to interaction between CMD and fraud level. Statistically, it is significantly probable for CMD with F-value $=4.184$ with alpha $=0.016$. Similar result when it is interacted with fraud level which shows F-value $=4.656$ at alpha $=0.010$. These findings indicate that the change in relationship between fraud level and whistleblowing score is influenced by CMD. In other words, the relationship variance of $\mathrm{CMD}$ and whistleblowing willingness could be explained by fraud level. This is similar to relation between CMD and cohesiveness level. The variance of the whistleblowing movement is different between the CMD (F $=3.177 ; \mathrm{p}=0.043$ ), while the level of cohesiveness is not so. However, when the cohesiveness interacts with CMD, statistical results show a significant number $(F=6.490$; $\mathrm{p}=0.002$ ). This results evidenced that APIP's variance of interest to blow the whistle among the three CMD groups is determined by differences in fraud level and cohesiveness. The variance of the whistleblowing interest score for APIPs in fraud level and cohesiveness is influenced by the degree of CMD of each group. Hence, the hypothesis (H6) that the interaction between antecedent variables in influencing the internal auditors' interest to be whistleblower is different according the stage of cognitive moral is acceptable.

\section{Results and discussions}

The above results that there is no significant difference of internal auditors' interest to become whistleblower due to different fraud level counter the previous study by Schultz et al. (1993), Kaplan and Whitecotton (2001), Ayers and Kaplan (2005) who examined the relationship between the seriousness of fraud and the interest of a person to whistleblow. APIP's decision of less considering the fraud level indicate high organisational and professional commitment to focus on higher future goals. Likewise, it is evidenced that the position level (status) of the wrongdoer does not significantly influence the whistleblowing willingness of APIPs. In other words, APIP will not lose his interest to blow the whistle only because of the status of person conducting fraud. This is contrary to the assumption saying that high power distance will cause an individual to not confront unethical behaviour of their boss (Goodwin and David, 1999). A hypotheses by Cortina and Magley (2003)
Table 9. Interaction between CMD and Treatment Variables (source: SPSS Output Result 2018)

\begin{tabular}{|c|c|c|c|c|}
\hline Variable & $\begin{array}{l}\text { Type III } \\
\text { Sum of } \\
\text { Squares }\end{array}$ & $\mathrm{df}$ & $\mathrm{F}$ & Sig \\
\hline \multicolumn{5}{|l|}{ Position Level } \\
\hline Intercept & 13192.16 & 1 & 4580.5 & 0.000 \\
\hline CMD & 3.218 & 2 & 0.558 & 0.572 \\
\hline Position & 3.999 & 1 & 1.389 & 0.239 \\
\hline CMD $\times$ Position & 10.413 & 2 & 1.808 & 0.165 \\
\hline \multicolumn{5}{|l|}{ Fraud Level } \\
\hline Intercept & 5587.77 & 1 & 1965.56 & 0.000 \\
\hline CMD & 23.781 & 2 & 4.183 & 0.016 \\
\hline Fraud & 0.238 & 1 & 0.084 & 0.772 \\
\hline $\mathrm{CMD} \times$ Fraud & 26.473 & 2 & 4.656 & 0.010 \\
\hline \multicolumn{5}{|l|}{ Cohesiveness } \\
\hline Intercept & 5269.43 & 1 & 1856.33 & 0,000 \\
\hline CMD & 18.034 & 2 & 3.177 & 0.043 \\
\hline Cohesiveness & 1.048 & 1 & 0.369 & 0.544 \\
\hline $\mathrm{CMD} \times$ Cohesiveness & 36.847 & 2 & 6.490 & 0.002 \\
\hline
\end{tabular}

that possible threat due to high position of the wrongdoer within an organisation which strengthens him to retaliate if someone attemps to trace becomes irrelevant in this study.

Furthermore, findings that do not support the hypothesis in terms of cohesiveness further reinforce that APIPs supports prosocial behavior. This finding conforms the evidences from Miller and Thomas (2005) that cohesiveness is only influential when interacting with position of wrongdoer. However, this empirical result differs from the findings of King (1997), Miller and Thomas (2005) who proposed that reporting the fraud conducted by close friend would be found less than if conducted by a non-friend. This is similar to Greenberger et al. (1987) suggesting that group of friendships are capable of creating an integrated power to force individuals to be silent when they notice unethical behaviour within organisation. The development of this research refers to the testing of variables suspected as the cause of APIPs with high probability of being a whistleblower despite their pragmatic level of CMD. A result of this study is that person with pragmatic level of CMD will tend to prioritize their personal interest than the institutions', which is contrary to the theoretical hypothesis, and hence they are predicted not to act as whistleblower.

\section{Conclusions, limitation and suggestion}

\section{Conclusions}

Results show that the minority of the internal auditors are categorised as autonomous group while majority as being 
pragmatic. Accommodation is in between both groups. The willingness of internal auditors to become whistleblower is high and insignificantly different among the CMD categories. The difference of willingness to whistleblow is also found insignificant in the variance of fraud level, wrongdoer's position level, and cohesiveness. However, the interaction between CMD and two treatment variables, fraud level and cohesiveness, contributes to the variance of whistleblowing movements. It generally can be concluded that APIPs are highly willing to become a whistleblower though not influenced by either variance in antecedent prosocial variables or their CMD level. However, when both CMD and fraud level/cohesiveness interact, the whistleblowing variance could be explained.

\section{Limitation}

The limitation of this research is due to the nature of the quasi experiment which is the probability of the participants to be less-focused in conducting the experiment treatment. They were required to work on the experiment in their workplace. Thus, because they were not directly controlled and supervised by the researchers. Consequently, the internal validity of this study could be threatened. Results of this study contribute to the theory, practice and governmental policy. The results strengthen the Kohlberg's cognitive moral development $(1971,1977)$ and prosocial organisational behaviour theory (Brief and Motowidlo 1986) in the context of the interaction of both in explaining the whistleblowing issue. The high interest of APIPs to whistleblow will imply on the effectiveness of BPK. As external auditor, BPK will obtain initial information about the object to be audited within organisation from the APIP. The finding of the high interest of APIP to blow the whistle also suggest the appropriateness of development program for APIPs to commit to organisation and prosocial. Furthermore, the implication of the findings on governmental policy, on the other hand, is the development of examination method as well as whistleblowing system design, that is, by making CMD the main determinant factor.

\section{Suggestion}

This research suggests further work of examining other treatments such as fraud frequency, previous BPK's opinion, fraud influence on BPK's opinion, and fraud orientation, religiosity moral development, and commitment to organization and profession in relation to APIPs' intention to whistleblow. Further research is also recommended to employ either laboratory or field research experiment model.

\section{References}

Ahmad SA (2011) Internal auditor and internal whistleblowing intentions: A study of organisational, individual, situational and demographic factor. Western Australia: Disertation. School of Accounting, Finance and Economics. Edith Cowan University.

Arnold DF Sr, Ponemon LA (1991) Internal auditors perceptions of whistleblowing and the influence of moral reasoning: An experiment. Auditing: A Journal of Practice and Theory $10(2): 1-15$.

Ayers S, Kaplan SE (2005) Wrongdoing by consultants: An examination of employees' reporting intentions. Journal of Business Ethics 57 (2): 121-137. https://doi.org/10.1007/ s10551-004-4600-0

Ayers S, Kaplan SE (2005) Wrongdoing by consultants: An examination of employees' reporting intentions. Journal of Business Ethics 57 (2): 121-137. https://doi.org/10.1007/ s10551-004-4600-0

Brennan N, Kelly J (2007) A study of whistleblowing among trainee auditors. The British Accounting Review 39 (1): 61-87. https://doi.org/10.1016/j.bar.2006.12.002

Brief AP S, Motowidlo JM (1986) Prosocial organizational behaviors. The Academy of Management Review 11 (4): 710-725. https://doi.org/10.5465/amr.1986.4283909

Clark MS (1981) Noncomparability of benefits given and received: A cue to the existence of friendship. Social Psychology Quarterly 44 (4): 375-381. https://doi.org/10.2307/3033907

Clark MS, Miller J (1979) Interpersonal attraction in exchange and communal relationships. Journal of Personality and Social Psychology 37 (1): 12-24. https://doi.org/10.1037/00223514.37.1.12

Cortina LM, Magley VJ (2003) Raising voice, risking retaliation: events following interpersonal mistreatment in the workplace. Journal of Occupational Health Psychology 8 (4): 247-265. https://doi.org/10.1037/1076-8998.8.4.247

Dozier JB, Marcia P Miceli (1985) Potential predictors of whistle-blowing: A prosocial behavior perspective. Academy of Management Review 10 (4): 823-836. https://doi.org/10.5465/ amr.1985.4279105

Elias A, Ryan L, Sulkes A, Collins J, Aisner J, Antman KH (1989) Response to mesna, doxorubicin, ifosfamide, and dacarbazine in 108 patients with metastatic or unresectable sarcoma and no prior chemotherapy. Journal of Clinical Oncology 7 (9): 1208-1216. https://doi.org/10.1200/JCO.1989.7.9.1208

Goodwin J, David G (1999) Ethical judgments across cultures: A comparison between business students from Malaysia and New Zealand. Journal of Business Ethics 18 (1): 267-281. https://doi.org/10.1023/A:1005785020162

Greenberger DB, Marcia P Miceli, Debra JC (1987) Oppositionists and group norms: The reciprocal influence of whistleblowers and co-workers. Journal of Business Ethics 6 (2): 527-542. https://doi.org/10.1007/BF00383744

Habbe AH, Alimuddin A Kusumawati, A Rura Y (2017) Cognitive moral development, organizational situation, and ethical decision making in business and accounting. Working Paper. 
Habbe AH, Mande H (2016) The effect of information sequential and personality on the investor belief revision. Ponte, International Scientific Researches Journal 72 (10): 150-166.

Hill GW (1982) Group versus individual performance: Are N+1 head better than one? Psychological Bulletin 91 (3): 517-539. https://doi.org/10.1037/0033-2909.91.3.517

Hofstede G (1980) Culture's consequences: international differences in work related values. Sage Publications, Beverly Hills, CA.

Hofstede G (1997) Cultures and Organizations: Software of the Mind. London: McGraw-Hill.

Hofstede G, Gert JH, Michael M (2010) Cultures and organisations: Software of the mind intercultural cooperation and its importance for survival. New York: McGraw-Hill.

Jones TM (1991) Ethical decision making by individuals in organizations: An issue-contingent model. Academy of Management Review 16 (2): 366-395. https://doi.org/10.5465/ amr.1991.4278958

Jubb B (2000) Auditors as whistleblowers. International Journal of Auditing 4 (1): 153-167. https://doi.org/10.1111/10991123.00310

Jubb PB (1999) Whistleblowing: A restrictive definition and interpretation. Journal of Business Ethics 21 (2): 77-94. https:// doi.org/10.1023/A:1005922701763

Kaplan SE, Whitecotton SM (2001) An examination of auditors' reporting intentions when another auditor is offered client employment. Auditing: A Journal of Practice and Theory 20 (1): 45-63. https://doi.org/10.2308/aud.2001.20.1.45

King G (1997) The Effects of interpersonal closeness and issue seriousness on blowing the whistle. The Journal of Business Communication 34 (4): 419-436. https://doi. org/10.1177/002194369703400406

Kohlberg L (1971) Stages of moral development as a basis of moral education. in Beck CM, Crittenden BS, Sullivan EV (pnyt.). Moral education: interdisciplinary approaches. New York: Newman Press, 23-92. https://doi. org/10.3138/9781442656758-004

Kohlberg L (1977) The cognitive-developmental approach to moral education. Dalam. Rogrs D. Issues in adolescent psychology. New Jersey: Printice Hall, Inc., 283-299.

Kohlberg L (1984) The psychology of moral development: The nature and validity of moral stages (Vol. 2). Harpercollins College Div.

Mattingly C (1991) What is clinical reasoning? The American Journal of Occupational Therapy 45 (11): 979-986. https:// doi.org/10.5014/ajot.45.11.979

Miceli MP (1994) Relationships among value congruence, perceived victimization, and retaliation against whistle-blowers. Journal of Management 20 (4): 773-794. https://doi. org/10.1177/014920639402000405

Miceli MP (1994) Relationships among value congruence, perceived victimization, and retaliation against whistle-blowers. Journal of Management 20 (4): 773-794. https://doi. org/10.1177/014920639402000405

Miceli MP, Janet P Near, Charles RS (1991) Who blows the whistle and why? Industrial and Labor Relations Review 45 (1): 113 130. https://doi.org/10.1177/001979399104500108
Miceli MP, Janet PN 1985) Characteristics of organizational climate and perceived wrongdoing associated with whistle-blowing decisions. Personnel Psychology 38 (2): 525-544. https://doi. org/10.1111/j.1744-6570.1985.tb00558.x

Miceli MP, Michael Rehg, Janet P Near, Katherine CR (1999) Can law protect whistle-blowers? Work and Occupations 26 (1): 129-151. https://doi.org/10.1177/0730888499026001007

Miller DL, Thomas T (2005) The impact of relative position and relational closeness on reporting of unethical acts. Journal of Business Ethics 61 (3): 315-328. https://doi.org/10.1007/ s10551-005-8771-0

Patel C (2003) Some cross-cultural evidence on whistle-blowing as an internal control mechanism. Journal of International Accounting Research 2 (1): 69-96. https://doi.org/10.2308/ jiar.2003.2.1.69

Rest JR (1979) Revised manual for the defining issues test: An objective test of moral judgment development. Minnesota Moral Research Projects.

Rest JR (1994) Background: Theory and Research James R. Rest. In Moral development in the professions. Psychology Press, 13-38.

Rushton JP, Chrisjohn RD, Fekken GC (1981) The altruistic personality and the self-report altruism scale. Personality and individual differences 2 (4): 293-302. https://doi. org/10.1016/0191-8869(81)90084-2

Sabang I (2013) Cheating, Fraud status, individual-group interaction, and interests being a whistleblower. Thesis Unpublished. Brawijaya University.

Schultz JJ Jr, Douglas A Johnson DM, Sverre D (1993) An investigation of the reporting of questionable acts in an international setting. Journal of Accounting Research 31 (1): 75-103. https://doi.org/10.2307/2491165

Tavakoli AA, Keenan JPB, Cranjak-K (2003) Culture and whistleblowing an empirical study of Croatian and United states managers utilizing hofstede's cultural dimensions. Journal of Business Ethics 43 (1): 49-64. https://doi. org/10.1023/A:1022959131133

Tharp K, Mattingly C (1991) Whistleblowing. Plastic surgical nursing: official journal of the American Society of Plastic and Reconstructive Surgical Nurses 11 (1): 33-34.

Tsaharidu EE, Wim V (2008) Organisational whistleblowing policies: Making employees responsible or liable? Journal of Business Ethics 82 (1): 107-118. https://doi.org/10.1007/ s10551-007-9565-3

Vandekerchove W (2006) Whistleblowing and organizational social responsibility: A global assessment. Ashgate Publishing Limited.

Witness \& Victim Protection Agency (2011) Understanding whistleblower. Witness and Victim Protection Agency. Jakarta.

Xu Y, Ziegenfuss DE (2008) Reward systems, moral reasoning, and internal auditors' reporting wrongdoing. Journal of Business and Psychology 22 (4):323-331. https://doi.org/10.1007/ s10869-008-9072-2 